\title{
Purifying Eutrophic Wastewater from Geese Farm with Plant Floating Bed in Winter
}

\author{
Xiaofeng Huang ${ }^{1 \#}$, Zuolan Liu ${ }^{1 \#}$, Jiajia Xue ${ }^{1 \#,}$ Yi Luo ${ }^{1}$, Changlian Zhang ${ }^{1}$, \\ Qigui Wang ${ }^{1,2}$, Anbin Leng ${ }^{4}$, Zhiping Zhu ${ }^{3 *}$, Chao Wang ${ }^{1,2 * *}$ \\ ${ }^{1}$ Chongqing Academy of Animal Sciences, Chongqing 402460, China \\ ${ }^{2}$ Scientific Observation and Experiment Station of Livestock Equipment Engineering in Southwest, \\ Ministry of Agriculture, Chongqing 402460, China \\ ${ }^{3}$ Institute of Environment and Sustainable Development in Agriculture, \\ Chinese Academy of Agricultural Sciences, Beijing 100081, China \\ ${ }^{4}$ Chongqing Qingshuiwan Breeder Geese Industry Limited Company, Dianjiang 408307, Chongqing, China
}

Received: 7 April 2020

Accepted: 27 July 2020

\begin{abstract}
The goal of this study was to compare the effects of three plants (ryegrass, chicory and cress) in floating bed systems on purification of sedimentation pond wastewater (low-concentration) and biogas slurry (high-concentration) from geese farm in winter. The results showed that the floating bed with ryegrass had better removal rates on chemical oxygen demand (COD), total nitrogen (TN) and total phosphorus (TP) of low-concentration wastewater than other groups at 60 days $(\mathrm{P}<0.05)$, and the removal rates were $53.0 \%, 83.3 \%$ and $61.1 \%$ respectively. At 90 days, cress has the best performance on removing 5- day biochemical oxygen demand $\left(\mathrm{BOD}_{5}\right)$ and turbidity $(\mathrm{P}<0.05)$, with a removal rate of $82.9 \%$ and $80.8 \%$. The removal rates of $\mathrm{BOD}_{5}, \mathrm{COD}, \mathrm{TN}$ and turbidity by ryegrass in highconcentration wastewater were significantly higher than other treatments $(\mathrm{P}<0.05)$, which were $84.0 \%$, $70.2 \%, 56.2 \%$ and $82.1 \%$ respectively. However, ryegrass had better stem height, root length and plant biomass production compared with cress and chicory. In conclusion, ryegrass was an optimal floating plant for purification of geese wastewater in winter and the optimal treatment time was 60 days. The regress has strong adaption for fluctuate concentrations of pollutants and is suitable for treatment of livestock and poultry wastewater in practice.
\end{abstract}

Keywords: wastewater, geese farm, plant floating bed

\section{Introduction}

In China, geese breeding stock had reached 146 million and the annual slaughter amount was more

\footnotetext{
\#These authors contributed equally to this work

*e-mail: zhuzhiping@caas.cn

**e-mail:wangccq@foxmail.com
}

548 million in 2018, accounting for more than $90 \%$ of the world's total amount $[1,2]$. Nowadays, with the expansion of the scale of geese breeding, the amount of wastewater produced by geese farms also increased. Due to the goose habit of playing with water and frequency water flushing for house, the total amount of wastewater from geese farm is relatively large [3]. 
Wastewater from geese farm has strong alkalinity and contains a large amount of nitrogen and phosphorus, and the proportion of pollutants in geese wastewater is different from that in livestock and other poultry wastewater. However, there are few researches concentrating on the treatment of wastewater from geese farm [4]. In practice, the anaerobic fermentation was still the common treatment for wastewater in geese farm. However, the wastewater after anaerobic fermentation contains large amounts of nutrients, such as nitrogen and phosphorus, and cannot be used or discharged directly. In addition, wastewater eutrophication is more serious in winter, and many traditional treatment methods are not recommended due to the high cost and low efficiency $[5,6]$. Therefore, it is necessary to explore how to treat wastewater economically and efficiently from geese farm in winter.

Plant treatment technology has the advantages of low cost, simple operation and no secondary pollution [7]. Researches have proven that plants could effectively remove nitrogen, phosphorus and other nutrients form wastewater [8-11]. Plant floating-bed system is an innovative technology which consists of terrestrial or aquatic plants growing in a hydroponic manner with buoyant frames floating on the surface of waters $[12,13]$. In previous research, the Phragmites australis and Canna indica floating bed system was used to treat urban river wastewater and the average mass removal rates of ammonia nitrogen $\left(\mathrm{NH}_{4}^{+}-\mathrm{N}\right)$, total nitrogen (TN), total phosphorus (TP), 5-day biochemical oxygen demand $\left(\mathrm{BOD}_{5}\right)$ and chemical oxygen demand (COD) reached $0.7,0.8,0.1,0.5$ and $2.5 \mathrm{~g} / \mathrm{m}^{2} \mathrm{~d}$, respectively [14].

Although it has been reported that plants have great application potential for wastewater purification [15-17], many plants with better purification effect in spring and summer cannot survive at low temperatures and will release their own pollutants into the water again, leading to more severe eutrophication [18]. Therefore, due to the low temperature, few plants are suitable for wastewater cultivation in winter [6, 19]. Meanwhile, because of the difference freeze resistant capacity, the removal rates of pollutants of wastewater in winter had big differences among plants. Research has found that yellow flag floating bed's removal rates of $\mathrm{TN}$ and TP are 2.82 and 5.31 times of canna because of more hardy in winter [20]. Therefore, the freeze resistant capacity has become an important factor restricting the application of economic plants in wastewater purification. As we know, geese are herbivorous birds, which have a great demand for pasture in geese farm. Meanwhile, ryegrass, chicory and cress are hardy plants in winter and also great feed for geese in China [21]. Therefore, it will be beneficial to use these plants in floating bed system to treat wastewater in winter and harvest as feed for goose. To investigate the effect of the plant (ryegrass, chicory and cress) floating bed system on the pollutants in the wastewater of geese farm in the cold environment, the present study was carried out on geese farm for 3 months in winter. In this work, the concentration of pollutants in wastewater and growth of several floating bed plants was monitored to find optimal plants and treatment period of treatment in low and high concentration wastewater.

\section{Materials and Methods}

\section{Experimental Materials and Floating Bed Design}

The experiment was performed in the poultry scientific research base of Chongqing Academy of Animal Science. The wastewater was obtained from biogas liquid and pond water separately after precipitation in the base, and the average concentration of pollutants are shown in Table 1. The ryegrass, chicory and cress were planted by the base. The ryegrass and chicory seeds grow in the soil and cress seeds were planted in water for 20 days until they reached the ideal size to be transferred to the defined location of the experiment. The self-made floating bed system was composed of double polyethylene net $(2 \mathrm{~cm} \times 2 \mathrm{~cm})$ and PVC tube, sized with $60 \times 30 \times 5 \mathrm{~cm}$ horizontal and vertical. The experiment was carried out in plastic cartons, sized with $80 \times 40 \times 30 \mathrm{~cm}$ horizontal and vertical.

\section{Testing Design}

The plants (ryegrass, chicory and cress) were rinsed with tap water, then divided into homogenous groups and acclimatized for 5 days in the same environmental conditions. Three plants with equal weight $(400 \mathrm{~g})$ were respectively planted into the floating bed at $60 \%$ coverage, then put into plastic cartons filled with pond water (low-concentration wastewater) and biogas liquid (high-concentration

Table 1. The initial concentration of pollutants in geese wastewater ${ }^{1}$.

\begin{tabular}{|c|c|c|c|c|c|c|c|}
\hline WCON $^{2}$ & $\begin{array}{c}\mathrm{BOD}_{5} \\
(\mathrm{mg} / \mathrm{L})\end{array}$ & $\begin{array}{c}\mathrm{COD} \\
(\mathrm{mg} / \mathrm{L})\end{array}$ & $\begin{array}{c}\mathrm{NH}_{4}^{+}-\mathrm{N} \\
(\mathrm{mg} / \mathrm{L})\end{array}$ & $\begin{array}{c}\mathrm{TP} \\
(\mathrm{mg} / \mathrm{L})\end{array}$ & $\begin{array}{c}\mathrm{TN} \\
(\mathrm{mg} / \mathrm{L})\end{array}$ & $\begin{array}{c}\text { Turbidity } \\
(\mathrm{NTU})\end{array}$ & $\mathrm{pH}$ \\
\hline Low & $24.22 \pm 0.42$ & $122.04 \pm 1.06$ & $59.56 \pm 0.49$ & $20.97 \pm 0.70$ & $64.53 \pm 0.85$ & $42.77 \pm 0.18$ & $8.19 \pm 0.06$ \\
\hline High & $100.98 \pm 1.52$ & $563.02 \pm 5.07$ & $324.01 \pm 3.06$ & $40.87 \pm 0.89$ & $338.99 \pm 7.06$ & $225.50 \pm 3.54$ & $8.37 \pm 0.03$ \\
\hline
\end{tabular}

${ }^{1}$ Data are shown as mean \pm SEM and each mean represent 3 samples;

${ }^{2}$ means concentration of wastewater (Low- water from sedimentation tank, High-biogas slurry). 
wastewater) respectively. A total of 6 treatment groups were set up in the experiment, each of 3 replicates. The information of group was as following: (1) L-CON: low-concentration wastewater without plant; (2) L-Rye: low-concentration wastewater with ryegrass floating bed system; (3) L-Cre: low-concentration wastewater with cress floating bed system; (4) L-Chi: low-concentration wastewater with chicory floating bed system; (5) $\mathrm{H}-\mathrm{CON}$ : high-concentration wastewater without plant; (6) H-Rye: high-concentration wastewater with ryegrass floating bed system; (7) H-Cre: high-concentration wastewater with cress floating bed system; (8) H-Chi: high-concentration wastewater with chicory floating bed system. The experiment was initiated from December 2018 to February 2019 and lasted for 3 months. During the experiment period, the temperature ranged from $4.1^{\circ} \mathrm{C}$ to $19.2^{\circ} \mathrm{C}$ and the mean temperature was approximately $9.4^{\circ} \mathrm{C}$.

\section{Pollutants Determination}

On day 0, 30, 60 and 90, water samples were collected to detect the concentration of pollutants which were composed of nitrogen, phosphorus, turbidity, $\mathrm{BOD}_{5}$ and $\mathrm{COD}$, and plant height and root length were also measured to monitor the growth of plants. TN, TP, $\mathrm{NH}_{4}^{+}-\mathrm{N}, \mathrm{BOD}_{5}, \mathrm{COD}, \mathrm{pH}$ and turbidity were measured according to the standard methods for water and wastewater monitoring and analysis (APHA, 2005) [22].

Plants were washed with tap water at the start and end of the experiment, and the average fresh plant weight was measured. The relative growth rate (RGR) was calculated as:

$$
\operatorname{RGR}(\%)=100 \times\left(\mathrm{W}_{\mathrm{e}}-\mathrm{W}_{\mathrm{i}}\right) / \mathrm{W}_{\mathrm{i}}
$$

...where $\mathrm{W}_{\mathrm{e}}$ is the average fresh weight of plants at the end of experiments, $\mathrm{W}_{\mathrm{i}}$ is the average initial fresh weight of plants.

The removal rate (RR) of pollutants in this study was calculated as:

$$
\operatorname{RR}(\%)=100 \times\left(\mathrm{C}_{\mathrm{i}}-\mathrm{C}_{\mathrm{t}}\right) / \mathrm{C}_{\mathrm{i}}
$$

...where $\mathrm{C}_{\mathrm{t}}$ is the average concentration of pollutants after treatment, $\mathrm{C}_{\mathrm{i}}$ is the average initial concentration of pollutants.

\section{Statistical Analysis}

All data calculation as averages and standard error of mean (SEM) were performed in Microsoft Excel 2016. Statistical analyses were carried out using Analysis of variance (ANOVA) in Software SPSS 20.0 (SPSS Inc., Chicago, IL, USA) including Bartlett's test for homogeneity of variances analysis and Duncan's test for differences between means. All statements of differences were based on a significance level of $\mathrm{P}<0.05$.

\section{Results}

The removal performances of plant floating bed system on pollutants in geese wastewater are shown in Table 2. The removal rates of $\mathrm{NH}_{4}^{+}-\mathrm{N}$ and turbidity in low-concentration wastewater were significantly higher than that in high-concentration group $(\mathrm{P}<0.05)$. As the growth time of floating bed plants goes on, the removal rates of all indexes increased, and reached the peak at day 60 . Among three floating bed system, the ryegrass had significantly higher removal rates of $\mathrm{TN}, \mathrm{TP}$, $\mathrm{NH}_{4}^{+}-\mathrm{N}$, turbidity and $\mathrm{pH}$ compared with other groups $(\mathrm{P}<0.05)$.

\section{Removal Performance of $\mathrm{BOD}_{5}$ by Plant Floating Bed System}

The removal efficiency of the plants floating bed system on $\mathrm{BOD}_{5}$ in geese wastewater is shown in Table 2 and Fig. 1. In low-concentration wastewater, $\mathrm{BOD}_{5}$ concentration in each group significantly decreased with time $(\mathrm{P}<0.05)$. The removal efficiency of $\mathrm{BOD}_{5}$ in three groups (ryegrass, cress and chicory) were significantly higher than control group at 90 days $(\mathrm{P}<0.05)$, which were $81.3 \%, 82.9 \%, 81.6 \%$ and $58.6 \%$, respectively. There was no significant difference among the treatment groups $(\mathrm{P}>0.05)$. In high-concentration groups, the $\mathrm{BOD}_{5}$ concentration of all treatment groups also presented a significant decrease along with time $(\mathrm{P}<0.05)$. At day 60 , the removal rates of $\mathrm{BOD}_{5}$ in ryegrass group was significantly higher than other groups $(\mathrm{P}<0.05)$, which was $84.0 \%$. There was no significant difference between cress and chicory group $(\mathrm{P}>0.05)$. After day 60, cress and chicory gradually died. The $\mathrm{BOD}_{5}$ concentration in ryegrass group reached a nadir at day 90 and the removal rate was $85.4 \%$, which was significantly lower than that in control group $(\mathrm{P}<0.05)$.

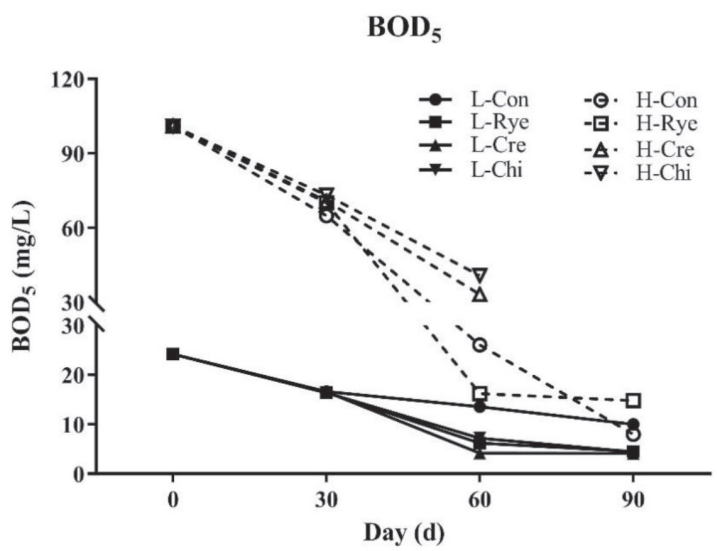

Fig. 1. The effect of plant floating bed on $\mathrm{BOD}_{5}$ in geese wastewater. 
Table 2. The removal rates of each nutrient and $\mathrm{pH}$ in wastewater of each group from geese farm $(\%)^{1}$.

\begin{tabular}{|c|c|c|c|c|c|c|c|c|c|c|}
\hline Group & $\mathrm{WCON}^{2}$ & Day & Plant & $\mathrm{BOD}_{5}$ & COD & $\mathrm{TN}$ & $\mathrm{NH}_{4}^{+}-\mathrm{N}$ & $\mathrm{TP}$ & Turbidity & $\mathrm{pH}$ \\
\hline 1 & Low & 30 & Control & 31.26 & 22.37 & 22.47 & 11.88 & 16.02 & 68.23 & -9.43 \\
\hline 2 & Low & 30 & Ryegrass & 32.09 & 22.95 & 32.33 & 15.24 & 13.02 & 62.46 & -4.95 \\
\hline 3 & Low & 30 & Cress & 31.40 & 22.40 & 42.34 & 11.59 & -1.91 & 68.61 & -2.70 \\
\hline 4 & Low & 30 & Chicory & 32.21 & 22.52 & 24.15 & 10.52 & -15.89 & 56.71 & -3.92 \\
\hline 5 & Low & 60 & Control & 43.90 & 15.14 & 100.00 & 33.95 & 54.35 & 35.84 & -8.91 \\
\hline 6 & Low & 60 & Ryegrass & 74.38 & 53.01 & 100.00 & 61.14 & 83.32 & 71.06 & -0.04 \\
\hline 7 & Low & 60 & Cress & 82.64 & 30.33 & 100.00 & 35.40 & 44.75 & 75.38 & -0.16 \\
\hline 8 & Low & 60 & Chicory & 70.17 & 28.08 & 100.00 & 18.66 & 49.00 & 63.49 & -0.04 \\
\hline 9 & Low & 90 & Control & 58.55 & 1.53 & 100.00 & 85.83 & 73.36 & -0.16 & -20.99 \\
\hline 10 & Low & 90 & Ryegrass & 81.27 & 17.49 & 100.00 & 56.79 & 93.72 & 55.79 & -3.48 \\
\hline 11 & Low & 90 & Cress & 82.92 & 38.80 & 100.00 & 53.51 & 58.71 & 80.81 & -6.99 \\
\hline 12 & Low & 90 & Chicory & 81.57 & 27.95 & 100.00 & 38.62 & 86.19 & 59.78 & -5.88 \\
\hline 13 & High & 30 & Control & 35.74 & 29.98 & 21.66 & 73.44 & 14.73 & 60.47 & -6.66 \\
\hline 14 & High & 30 & Ryegrass & 30.59 & 31.85 & 16.87 & 53.55 & 10.42 & 64.82 & -2.30 \\
\hline 15 & High & 30 & Cress & 29.93 & 31.91 & 19.03 & 47.27 & -6.10 & 58.76 & -2.15 \\
\hline 16 & High & 30 & Chicory & 27.51 & 25.04 & 26.79 & 42.61 & 4.94 & 46.53 & -2.67 \\
\hline 17 & High & 60 & Control & 74.20 & 40.35 & 52.62 & 80.29 & 41.62 & 66.37 & -13.07 \\
\hline 18 & High & 60 & Ryegrass & 83.96 & 70.16 & 61.57 & 50.04 & 56.16 & 82.07 & -2.11 \\
\hline 19 & High & 60 & Cress & 67.13 & 27.83 & 36.32 & 53.14 & 27.63 & 62.56 & -2.62 \\
\hline 20 & High & 60 & Chicory & 59.68 & 38.79 & 35.19 & 50.99 & 23.85 & 60.23 & -2.64 \\
\hline 21 & High & 90 & Control & 92.08 & 54.81 & 81.29 & 78.65 & 76.25 & 78.85 & -9.91 \\
\hline 22 & High & 90 & Ryegrass & 85.35 & 50.27 & 46.40 & 55.34 & 44.25 & 69.16 & -6.04 \\
\hline 23 & High & 90 & Cress & - & - & - & - & - & - & - \\
\hline 24 & High & 90 & Chicory & - & - & - & - & - & - & - \\
\hline \multicolumn{4}{|c|}{ SEM $^{3}$} & 3.22 & 2.32 & 4.33 & 4.51 & 3.13 & 2.18 & 0.66 \\
\hline \multicolumn{11}{|c|}{$\mathrm{P}_{\text {value }}{ }^{4}$} \\
\hline \multicolumn{4}{|c|}{ WCON } & 0.33 & 0.33 & 0.80 & 0.00 & 0.80 & 0.02 & 0.00 \\
\hline \multicolumn{4}{|c|}{ Day } & 0.00 & 0.03 & 0.00 & 0.68 & 0.00 & 0.00 & 0.00 \\
\hline \multicolumn{4}{|c|}{ Plant } & 0.99 & 1.00 & 0.02 & 0.00 & 0.00 & 0.00 & 0.00 \\
\hline \multicolumn{4}{|c|}{ WCON*Day } & 0.00 & 0.00 & 0.00 & 0.00 & 0.09 & 0.00 & 0.00 \\
\hline \multicolumn{4}{|c|}{ WCON*Plant } & 0.55 & 0.92 & 0.00 & 0.05 & 0.00 & 0.02 & 0.18 \\
\hline \multicolumn{4}{|c|}{ Day*Plant } & 0.00 & 0.00 & 0.00 & 0.01 & 0.00 & 0.00 & 0.00 \\
\hline \multicolumn{4}{|c|}{ WCON*Day*Plant } & 0.00 & 0.25 & 0.00 & 0.00 & 0.00 & 0.00 & 0.00 \\
\hline
\end{tabular}

${ }^{1}$ Data are shown as mean and each mean represent 3 samples;

${ }^{2}$ means concentration of wastewater (Low- water from sedimentation tank, High-biogas slurry);

${ }^{3}$ means standard error of mean;

${ }^{4}$ WCON/Day/Plant: mean main effects of water concentration/day/plant; WCON*Day: means interaction of water concentration and plant; WCON*Plant: means interaction of water concentration and plant; Day*Plant: means interaction of day and plant; WCON*Day*Plant: means interaction of water concentration, day and plant. 


\section{COD}

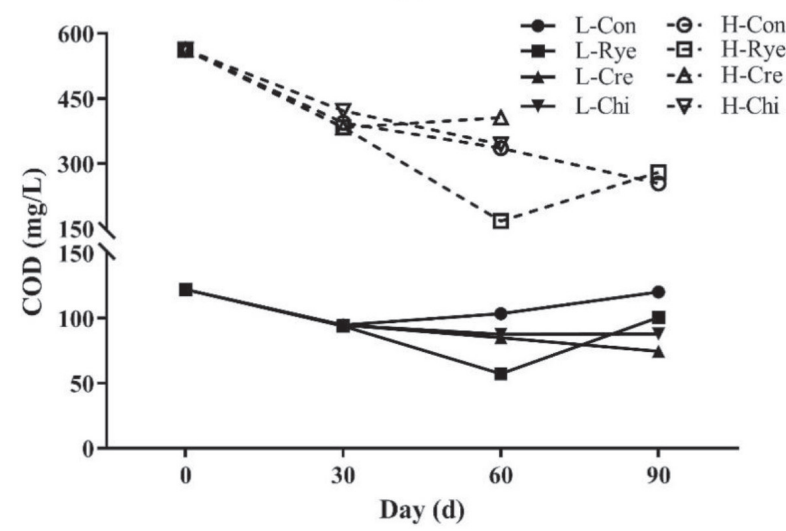

Fig. 2. The effect of plant floating bed on COD in geese wastewater.

\section{Removal Performance of COD by the Floating Bed System}

The removal efficiency of the plants floating bed system on COD in wastewater is shown in Table 2 and Fig. 2. The removal effect of COD was mainly affected by processing time, in which processing time interacts with concentration, time and floating bed plant species, and there is no interaction between concentration and plants. In low-concentration groups, the concentration of COD at day 60 was significantly higher than that at day 30 and $90(\mathrm{P}<0.05)$ and no significant difference was found between day 30 and day $90(\mathrm{P}>0.05)$. At day 60 , ryegrass group had significant lower $\mathrm{COD}$ concentration than other groups $(\mathrm{P}<0.05)$ and the removal rate reached $53.0 \%$. There was no significant difference between the cress and chicory groups $(\mathrm{P}>0.05)$. In highconcentration groups, the COD concentration presented a significant decrease along with times $(\mathrm{P}<0.05)$. At day 60 , the removal rate of COD reached a peak of $70.2 \%$ in ryegrass group, which was significantly higher than that

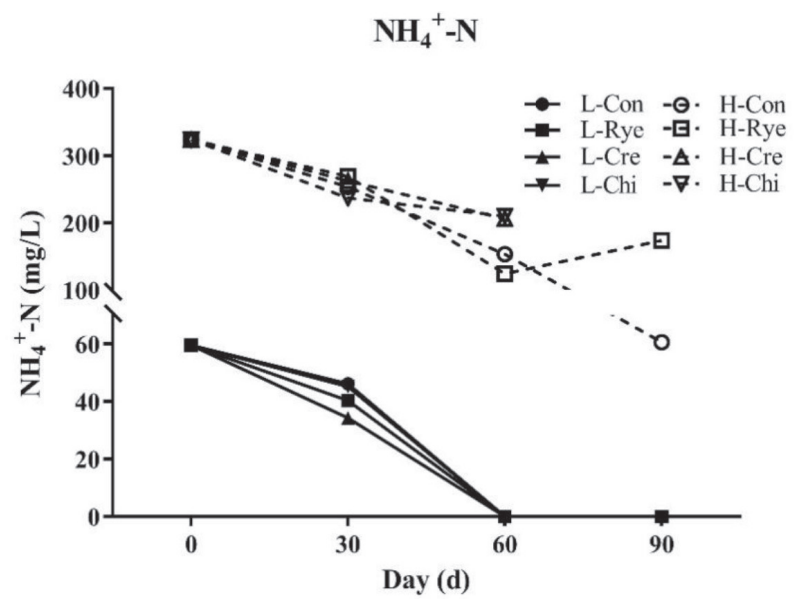

Fig. 3. The effect of plant floating bed on $\mathrm{NH}_{4}{ }^{+}-\mathrm{N}$ in geese wastewater. in other groups $(\mathrm{P}<0.05)$. However, the COD removal rate had no significant difference between cress and chicory group, which were both significantly lower than in control group $(\mathrm{P}<0.05)$. Meanwhile, there was no significant difference between control and ryegrass group at day $90(\mathrm{P}>0.05)$.

\section{Removal Performance of $\mathrm{NH}_{4}^{+}$-N Removal by the Floating Bed System}

The removal efficiency of the plants floating bed system on $\mathrm{NH}_{4}^{+}-\mathrm{N}$ in wastewater is showed in Table 2 and Fig. 3. In low-concentration groups, the ryegrass and cress group had significant higher removal rates of $\mathrm{NH}_{4}^{+}-\mathrm{N}$ compared with other groups at day 30 $(\mathrm{P}>0.05)$, with the removal rates were $32.3 \%$ and $42.3 \%$ respectively. At day 60 and 90 , the $\mathrm{NH}_{4}{ }^{+} \mathrm{N}$ could not be detected in both control and treatment group, and all the removal rates reached $100 \%$. Along with the whole experimental period, the removal rates in highconcentration groups significantly increased $(\mathrm{P}<0.05)$. However, no significant difference was found among four groups at day $30(\mathrm{P}>0.05)$. At day 60 , the cress and chicory group had significant lower removal rates compared with control and ryegrass group $(\mathrm{P}<0.05)$ and there was no significant difference between control and ryegrass group $(\mathrm{P}>0.05)$. However, the removal rate in ryegrass group was significantly lower than that in control group at day $90(\mathrm{P}<0.05)$.

\section{Removal Performance of TN by the Floating Bed System}

The removal efficiency of the plants floating bed system on TN in is shown in Table 2 and Fig. 4. Three factors (wastewater concentration, processing time and the floating bed plant species) have synergistic effect on the effect of $\mathrm{TN}$ removal. In low-concentration groups, the TN concentrations show a significant reduction along with time $(\mathrm{P}<0.05)$. At day 30 , the

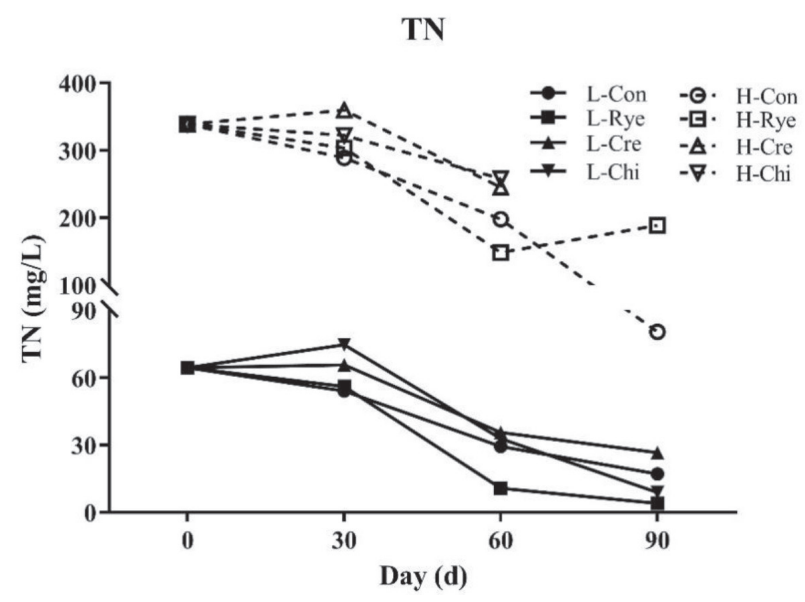

Fig. 4. The effect of plants floating bed on TN in geese wastewater. 
cress and chicory group had significantly lower TN removal rates compared with control and ryegrass group $(\mathrm{P}<0.05)$. The ryegrass has highest $\mathrm{TN}$ removal rate among four groups at day $60(\mathrm{P}<0.05)$, which was $83.3 \%$, and no significant difference was found among the other three groups $(\mathrm{P}>0.05)$. The $\mathrm{TN}$ removal rates in ryegrass and chicory group were significantly higher than that in control and cress group at day 90 $(\mathrm{P}<0.05)$, which were $93.7 \%$ and $86.2 \%$, respectively. Similarly, the TN concentrations in high-concentration groups significantly decreased with time $(\mathrm{P}<0.05)$. At day 30, there was no significant difference among ryegrass, cress and control group $(\mathrm{P}>0.05)$ and the TN concentration in cress was significantly higher than other groups $(\mathrm{P}<0.05)$. The removal rates in ryegrass group was significantly higher than other groups at day $60(\mathrm{P}<0.05)$, which was $56.2 \%$. However, the ryegrass group had significant lower $\mathrm{TN}$ removal rates compared with control $(\mathrm{P}>0.05)$.

\section{Removal Performance of TP by the Floating Bed System}

The removal efficiency of the plants floating bed system on TP in wastewater is shown in Table 2 and Fig. 5. Similar to $\mathrm{TN}$, three factors have synergistic effect on the removal effect of TP, in which the concentration effect is weak. In low-concentration groups, the TP content showed a significant decrease along with time $(\mathrm{P}<0.05)$. At day 60 , the TP removal rate in ryegrass group reached $61.1 \%$, which was significantly higher than other groups $(\mathrm{P}<0.05)$. However, the TP removal rates in three treatment groups at day 90 were significantly lower than control $(\mathrm{P}<0.05)$. In high-concentration groups, there was no significant difference on removal rates among four groups at day 30 and day $60(\mathrm{P}>0.05)$. At day 90, the removal rate in ryegrass group was significantly lower than control $(\mathrm{P}<0.05)$.

TP

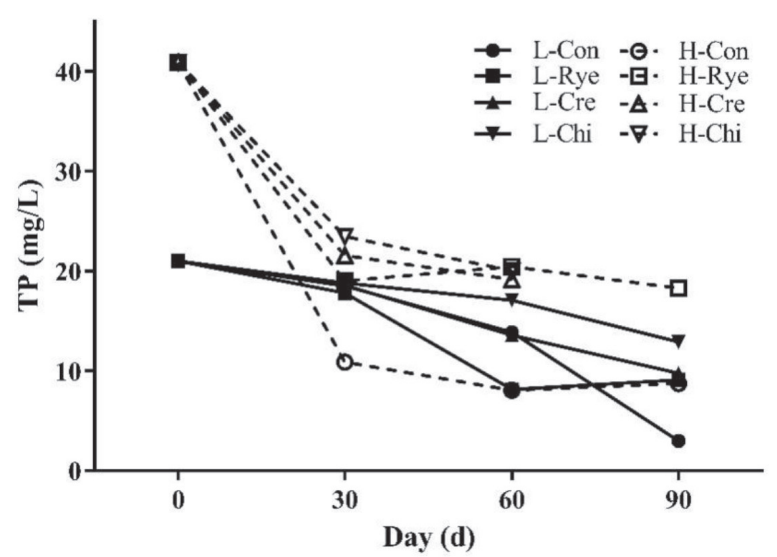

Fig. 5. The effect of plant floating bed on TP in geese wastewater.
Removal Performance of Turbidity and $\mathrm{pH}$ Value by the Floating Bed System

The removal efficiency of the plants floating bed system on turbidity and $\mathrm{pH}$ in wastewater is shown in Table 2, Figs 6 and 7. Turbidity and $\mathrm{pH}$ in wastewater are affected by three factors (wastewater concentration, processing time and the floating bed plant species), and these factors have synergistic effect. In lowconcentration groups, the turbidity concentration was significantly reduced at day 90 compared with that at day 30 and $60(\mathrm{P}<0.05)$. Three treatment groups had significantly higher removal rates than control at day 60 and day $90 \quad(\mathrm{P}<0.05)$. The removal rate reached a peak of $80.8 \%$ in cress group at day 90 , which was significantly higher than that in ryegrass and chicory group ( $\mathrm{P}<0.05)$. However, in high-concentration group, the removal rates reached a peak of $82.1 \%$ in ryegrass group at day 60 , which was significantly higher than other groups $(\mathrm{P}<0.05)$. At day 90 , the ryegrass group had significantly lower removal rates than control $(\mathrm{P}<0.05)$.

Turbidity

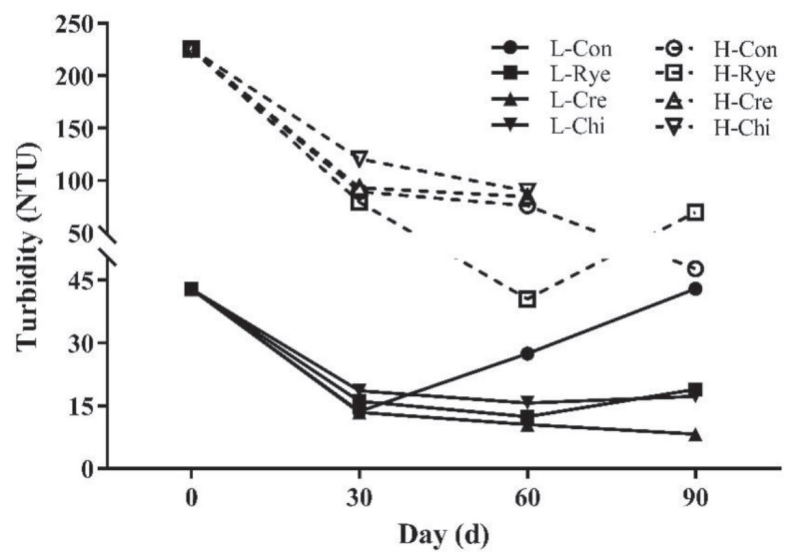

Fig. 6. The effect of plant floating bed on Turbidity in geese wastewater.

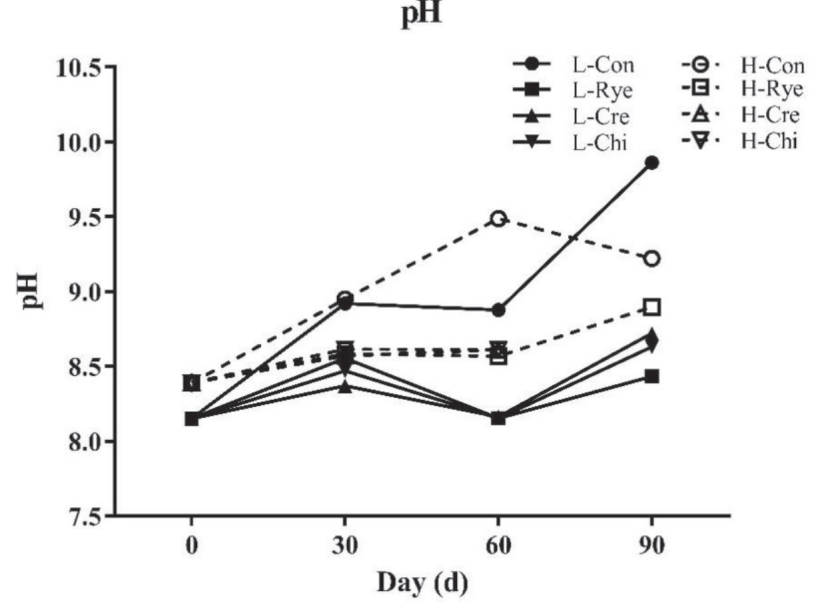

Fig. 7. The effect of plant floating bed on $\mathrm{pH}$ in geese wastewater. 
Throughout the whole experimental period, $\mathrm{pH}$ in all treatment group presented a significant increase compared to control $(\mathrm{P}<0.05)$. At day 60, $\mathrm{pH}$ in treatment group of low-concentration wastewater had lower values than that at day 30 and day $90(\mathrm{P}<0.05)$, which were $8.57,8.61$ and 8.61 for ryegrass, cress and chicory group. However, no significant difference was found among three treatment groups $(\mathrm{P}>0.05)$. In highconcentration group, there was no significant difference on $\mathrm{pH}$ between day 30 and day 60 and among three groups $(\mathrm{P}>0.05)$. At day 90, the ryegrass group had significantly higher $\mathrm{pH}$ than that at day 30 and 60 $(\mathrm{P}<0.05)$.

\section{Growth Performance of Plants in Floating Bed System}

The growth of the plants in the floating bed system in wastewater is shown in Table 3 and Table 4. Plant growth rate is closely related to species, wastewater concentration and growth time. Throughout the whole experimental period, the stem height and root length of plants in low-concentration group were significantly higher than that in biogas liquid group $(\mathrm{P}<0.05)$, except for cress and chicory at day 30. At day 60 and 90 , the stem height and root length of each plant had significantly higher values compared with that at day 0 in low- and high-concentration wastewater $(\mathrm{P}<0.05)$. For the RGR, the ryegrass in low-concentration group had significantly higher values than that in cress and chicory group and high-concentration group $(\mathrm{P}<0.05)$, which was $544.4 \%$.

\section{Discussion}

\section{The Pollutants Removal by Plant Floating Bed System}

The plant-floating system could form a biofilm with a large surface area for the purification of water by both epiphyte and microbes [19]. The epiphyte could contact wastewater to absorb, transform and degrade the pollutants, and secrete large amount of enzyme and organic acid to accelerate the decomposition of the macromolecular pollutants and improve the bioavailability of nitrogen and phosphorus in wastewater [23]. Meanwhile, plant-floating system will bring various bacteria involved in pollutants degradation and removal into wastewater [24]. In the present study, the plant floating bed system could significantly improve the removal rates of $\mathrm{BOD}_{5}, \mathrm{COD}, \mathrm{TN}$ and turbidity in wastewater compare with control in winter. This was similar to previous studies on the purification of rivers by plant floating bed systems, which can effectively remove pollutants from the water [14, 25-27]. These results indicated that three plants (ryegrass, cress and chicory) could adapt the low temperature and effectively remove pollutants from geese wastewater. Besides, the results found that the floating bed system with ryegrass had better removal effects on COD, TN and TP of wastewater than other groups at day 60, and the removal rate of them in different concentrations of wastewater were $53.0 \sim 70.2 \%, 56.2 \sim 83.3 \%$ and 50.0 61.1\%. Similarly, previous research found that

Table 3. The weight and relative growth rate of plants in each treatment group ${ }^{1}$.

\begin{tabular}{|c|c|c|c|c|c|}
\hline \multirow{2}{*}{ Wi $(\mathrm{g})$} & \multicolumn{2}{|c|}{ We $(\mathrm{g})$} & \multicolumn{2}{c|}{ RGR $(100 \%)$} \\
\cline { 4 - 6 } & & Low & High & Low & High \\
\hline \multirow{2}{*}{ Ryegrass } & \multirow{3}{*}{400} & $2577.92 \pm 156.13^{\mathrm{Aa}}$ & $1576.11 \pm 22.63^{\mathrm{B}}$ & $544.40 \pm 39.01^{\text {Aa }}$ & $294.02 \pm 5.61^{\mathrm{B}}$ \\
\cline { 1 - 3 } & & $1130.64 \pm 75.81^{\mathrm{b}}$ & - & $182.62 \pm 18.92^{\mathrm{b}}$ & - \\
\cline { 1 - 4 } Cress & $674.62 \pm 30.10^{\mathrm{c}}$ & - & $68.61 \pm 7.52^{\mathrm{c}}$ & - \\
\cline { 1 - 4 } & & & &
\end{tabular}

${ }^{1}$ Data are shown as mean \pm SEM and each mean represent 3 samples;

A,b,c Different letters in the same column indicate significant differences among three treatments $(\mathrm{P}<0.05)$;

${ }_{\mathrm{A}, \mathrm{B}}$ Different letters in the same row indicate significant differences between two concentrations $(\mathrm{P}<0.05)$.

Table 4. The stem height and root length of plants in each group.

\begin{tabular}{|c|c|c|c|c|c|c|c|c|c|c|c|c|c|}
\hline & & \multicolumn{4}{|c|}{ Low } & \multicolumn{4}{|c|}{ High } & \multirow{2}{*}{ SEM } & \multicolumn{3}{|c|}{$P$ value } \\
\hline & & 0 & 30 & 60 & 90 & 0 & 30 & 60 & 90 & & Day & WCON & WCON*Day \\
\hline \multirow{2}{*}{ Ryegrass } & Stem height & 7.97 & 34.33 & 72.83 & 88.00 & 7.97 & 31.67 & 69.33 & 79.00 & 1.66 & 0.00 & 0.00 & 0.08 \\
\hline & Root length & 3.96 & 12.00 & 29.17 & 30.00 & 3.96 & 5.16 & 13.26 & 13.33 & 4.20 & 0.00 & 0.00 & 0.00 \\
\hline \multirow{2}{*}{ Cress } & Stem height & 4.95 & 8.17 & 35.83 & 43.67 & 4.95 & 6.03 & 10.33 & - & 4.51 & 0.00 & 0.00 & 0.00 \\
\hline & Root length & 3.97 & 4.33 & 20.67 & 22.33 & 2.01 & 2.30 & 17.00 & - & 0.91 & 0.00 & 0.01 & 0.02 \\
\hline \multirow{2}{*}{ Chiccory } & Stem height & 4.96 & 5.17 & 18.67 & 22.34 & 4.96 & 5.07 & 15.03 & - & 0.59 & 0.00 & 0.01 & 0.00 \\
\hline & Root length & 0.97 & 1.00 & 16.67 & 18.10 & 0.97 & 2.33 & 7.00 & - & 0.24 & 0.00 & 0.00 & 0.00 \\
\hline
\end{tabular}


H. vulgaris showed the best performance for nitrogen treatment among four plants, and the average removal rates of $\mathrm{TN}$ were $70.7 \%$ and $87.7 \%$ under high and low influent concentration [28]. These indicated that the purification efficiency of plant floating bed system would depend on the plant species and wastewater concentration [23].

We found that the removal amount of nutrients was positively correlated with the concentration of wastewater after the treatment of plant floating bed system. The results shown that ryegrass floating bed system in high concentration wastewater can remove 3.5 times of $\mathrm{TN}$ compared to low concentration wastewater, and other pollutants $\left(\mathrm{TP}, \mathrm{NH}_{4}^{+}-\mathrm{N}, \mathrm{COD}\right.$ and $\mathrm{BOD}_{5}$ ) had similar trends, when the initial plant biomass were same in different concentration wastewater. Previous researchers also found a positive correlation between removal rates of $\mathrm{TN}$ and $\mathrm{TP}$ in wastewater and growth speed of plants in floating boat system $[29,30]$. Our study proved that the removal rates of TN and TP in the low-concentration wastewater by the ryegrass floating bed system $(83.3 \%$ and $61.1 \%)$ was more than 1.5 times of that by cress $(44.8 \%$ and $35.4 \%)$ and chicory ( $49.0 \%$ and $18.7 \%$ ), while RGR in ryegrass was more than 3 times compared to cress and chicory.

In the present study, the removal rates of $\mathrm{BOD}_{5}$, $\mathrm{COD}, \mathrm{TP}$, turbidity and $\mathrm{pH}$ at day 60 were higher than that at day 30 and 90, especially for high concentration wastewater. The trend might be related to that plant growth characteristics. Ryegrass and chicory belong to herbage and they could be harvested at a certain stage of growth to promote regrowth and development of utilization rate [26]. The plants in this experiment might have reached the growth maturity at day 60 , and the removal efficiency of pollutants would not be further improved with time. The speculation was also proved by that no difference was found between day 60 and 90 on the stem height and root length of plants.

The $\mathrm{pH}$ value has a special restrictive effect on some types of organisms, and can also influence precipitation and the dissolution of substances [31]. In this experiment, the increase of $\mathrm{pH}$ value may also restrict the purification efficiency of plants due to that the removal rates of pollutants increased from day 30 to day 60 while $\mathrm{pH}$ decreased in low concentration wastewater. However, the mechanism is not clear and needs further study. In this experiment, the wastewater in control groups became cloudy and light green, which might lead to the increase of turbidity later in the experiment [32]. The phenomenon indicated that the nutrient in wastewater will stimulate algae in plant-absent condition and the algae might contained Cyanobacteria [33]. Therefore, even lower concentration of nutrients found in control on day 60 compared to cress and chicory group, the algae will pollute the environment if the control wastewater were discharged into the environment. Therefore, the control treatment (no plants) will not have an environmentally friendly approach compared to constructed wetlands.

\section{Effects on Plant Growth}

Biomass yields were influenced by the environment, morphology and physiology of the plant, as many species have different mechanisms for aquatic/drought adaptation, including the enhancement of root systems, adjustments to growth rate, modifications to plant structure, and more efficient water utilization [34, 35]. In the present experiment, the ryegrass had higher biomass and more developed roots in same condition compared to cress and chicory. The fresh weight, stem height and root length of ryegrass in low-concentration wastewater were 2.3 times, 2 times and 1.3 times of cress and 3.9 times, 3.9 times and 1.7 times of chicory, and similar results were found in high-concentration wastewater. The efficiency of pollutants removal by the plant floating bed systems depends upon plant biomass production and pollutants concentrations in wastewater $[8,36]$. This might explain that ryegrass had higher removal rates for pollutants as mentioned above. In addition, the harvest of floating bed plants can be used as green feed to feed geese and has an economic value, which indicated that higher plant yield is more conducive to save feed costs. Under the experimental conditions, the biomass of ryegrass was much greater than that of water cress and chicory, so the use of ryegrass floating bed system could also benefit for reducing feed costs in geese farm.

In high-concentration wastewater, only ryegrass among three plants could grow normally at day 90, which indicated that ryegrass has strong resistance for high concentration pollutants. As we know, the concentration of wastewater will fluctuate within a certain range according to the actual situation of farms, the strong adaption characteristic of ryegrass is suitable for the treatment of different livestock and poultry wastewater.

In our study, plants in low concentration wastewater presented higher RGR compared to high concentration wastewater, with $544.4 \%$ for low-concentration and $294.0 \%$ for high-concentration wastewater. Compared to high-concentration wastewater, three plants in lowconcentration wastewater had longer root and stems at 60 days, which was consistent with previous report [37]. As a crucial factor, the concentration of wastewater played an important role in plant growth, and lowconcentration wastewater was more suitable for plant growth in floating boat system.

\section{Conclusion}

In winter, the ryegrass, cress and chicory could adapt the low temperature and the corresponding floating island system could effectively remove pollution from geese wastewater. The ryegrass had better removal efficiency on pollutants compared to cress and ryegrass in two concentrations of wastewater at day 60. Therefore, the optimal plants for geese wastewater 
treatment was ryegrass and the optimal treatment time was 60 days. Besides, the low-concentration wastewater was more suitable for plant growth and the highconcentration wastewater would repress the growth of three plants in floating bed. The regress has strong adaption for fluctuate concentrations of wastewater and is suitable for the treatment of livestock and poultry wastewater in the future.

To increase the removal efficiency in the application, the ryegrass floating bed system also can be used at the same time in biogas slurry pond and sedimentation pond in winter.

\section{Acknowledgements}

This study was supported by the Earmarked Fund for China Agriculture Research System (CARS-4222), the Earmarked Fund for Chongqing Rongchang Agriculture and Animal Husbandry High-tech Industry Research and Development (cstc2019ngzx0017), and the Earmarked Fund for Chongqing Technology Innovation and Application Development (cstc2019jscxlyjsAX0013).

\section{Conflict of Interest}

The authors declare no conflict of interest.

\section{Reference}

1. WANG B.-W. Current Status and Prospects of Nutritional Value Evaluation and Nutritional Demand of Goose Feed. China Poultry, 41, 1, 2019.

2. HOU S.-S. Current status, future trends and suggestions of waterfowl industry in 2018. Chinese Journal of Animal Science, 55, 124, 2019.

3. LOYN R.H., SWINDLEY R.J., STAMATION K. Waste water not wasted: the Western treatment plant as a habitat for waterfowl. Victorian Naturalist, The, 131, 147, 2014.

4. HUANG X., LUO Y., LIU Z., ZHANG C., ZHONG H., XUE J., WANG Q., ZHU Z., WANG C. Influence of Two-Stage Combinations of Constructed Wetlands on the Removal of Antibiotics, Antibiotic Resistance Genes and Nutrients from Goose Wastewater. International journal of environmental research and public health, 16, 4030, 2019.

5. YANG X.-E., WU X., HAO H.-L., HE Z.-L. Mechanisms and assessment of water eutrophication. Journal of Zhejiang University Science B, 9, 197, 2008.

6. ZHAO F., XI S., YANG X., YANG W., LI J., GU B., HE Z. Purifying eutrophic river waters with integrated floating island systems. Ecological Engineering, 40, 53, 2012.

7. WU Q., HU Y., LI S., PENG S., ZHAO H. Microbial mechanisms of using enhanced ecological floating beds for eutrophic water improvement. Bioresource technology, 211, 451, 2016.

8. WANG J., ZHI Y., SONG Y. Purification Effect of Water Hyacinth (Eichhornia crassipes) Coverage on the Different
Flow Properties Water Bodies. Ecology and Environmental Sciences, 21, 124, 2012.

9. STEWART F.M., MUHOLLAND T., CUNNINGHAM A.B., KANIA B.G., OSTERLUND M.T. Floating islands as an alternative to constructed wetlands for treatment of excess nutrients from agricultural and municipal wastesresults of laboratory-scale tests. Land Contamination \& Reclamation, 16, 25, 2008.

10. LUO S., ZHANG Y., LI J., HUANG Z., HUO H., DONG Y. Effect of combination of submerged macrophyte with ecological floating bed on aquacultural pollution controlling. Journal of Ecology and Rural Environment, 27, 87, 2011.

11. MASTERS B. The ability of vegetated floating Islands to improve water quality in natural and constructed wetlands: a review. Water Practice and Technology, 7, 2012.

12. HU G.-J., ZHOU M., HOU H.-B., ZHU X., ZHANG W.-H. An ecological floating-bed made from dredged lake sludge for purification of eutrophic water. Ecological Engineering, 36, 1448, 2010.

13. BOUTWELL J.E. Preliminary field studies using vegetated floating platforms; US Department of the Interior, Bureau of Reclamation: 1995.

14. SAEED T., PAUL B., AFRIN R., AL-MUYEED A., SUN G. Floating constructed wetland for the treatment of polluted river water: A pilot scale study on seasonal variation and shock load. Chemical Engineering Journal, 287, 62, 2016.

15. VAILLANT N., MONNET F., SALLANON H., COUDRET A., HITMI A. Treatment of domestic wastewater by an hydroponic NFT system. Chemosphere, 50, 121, 2003.

16. GRABER A., JUNGE R. Aquaponic Systems: Nutrient recycling from fish wastewater by vegetable production. Desalination, 246, 147, 2009.

17. MAGWAZA S.T., MAGWAZA L.S., ODINDO A.O., MDITSHWA A. Hydroponic technology as decentralised system for domestic wastewater treatment and vegetable production in urban agriculture: A review. Science of The Total Environment, 698, 134154, 2019.

18. MISHRA S., MAITI A. The efficiency of Eichhornia crassipes in the removal of organic and inorganic pollutants from wastewater: a review. Environmental science and pollution research, 24, 7921, 2017.

19. HU M.-H., YUAN J.-H., YANG X.-E., HE Z.-L. Effects of temperature on purification of eutrophic water by floating eco-island system. Acta Ecologica Sinica, 30, 310, 2010.

20. WU L., CONG H., WANG X., ZHANG Q.-L. Effect of three kinds of floating-bed plants and artificial plants on nitrogen and phosphorus removal in water. Environmental Science and Technology, 23, 12, 2012.

21. LANGWORTHY A.D., RAWNSLEY R.P., FREEMAN M.J., CORKREY R., PEMBLETON K.G., HARRISON M.T., LANE P.A., HENRY D.A. Effect of stubble height and irrigation management on the growth, botanical composition and persistence of perennial ryegrass, tall fescue and chicory swards in cool-temperate Tasmania. Crop and Pasture Science, 70, 169, 2019.

22. FEDERATION W.E., ASSOCIATION A.P.H. Standard methods for the examination of water and wastewater. American Public Health Association (APHA): Washington, DC, USA, 2005.

23. DENG Y., NI F. Review of ecological floating bed restoration in polluted water. Journal of Water Resource and Protection, 5, 1203, 2013. 
24. SUN Z., XIE D., JIANG X., FU G., XIAO D., ZHENG L. Effect of eco-remediation and microbial community using multilayer solar planted floating island (MS-PFI) in the drainage channel. bioRxiv, 327965, 2018.

25. CAO W., WANG Y., SUN L., JIANG J., ZHANG Y. Removal of nitrogenous compounds from polluted river water by floating constructed wetlands using rice straw and ceramsite as substrates under low temperature conditions. Ecological Engineering, 88, 77, 2016.

26. NING D., HUANG Y., PAN R., WANG F., WANG H. Effect of eco-remediation using planted floating bed system on nutrients and heavy metals in urban river water and sediment: a field study in China. Science of the total environment, 485, 596, 2014.

27. LUO J., LI X., MA R., LI F., DUAN H., HU W., QIN B., HUANG W. Applying remote sensing techniques to monitoring seasonal and interannual changes of aquatic vegetation in Taihu Lake, China. Ecological Indicators, 60, 503, 2016.

28. DUAN J., ZHAO J., XUE L., YANG L. Nutrient removal of a floating plant system receiving lowpollution wastewater: Effects of plant species and influent concentration. In Proceedings of IOP Conference Series: Earth and Environmental Science; p. 012028.

29. FOX L., STRUIK P., APPLETON B., RULE J. Nitrogen phytoremediation by water hyacinth (Eichhornia crassipes (Mart.) Solms). Water, Air, and Soil Pollution, 194, 199, 2008.

30. JAYAWEERA M.W., KASTURIARACHCHI J.C., KULARATNE R.K., WIJEYEKOON S.L. Contribution of water hyacinth (Eichhornia crassipes (Mart.) Solms) grown under different nutrient conditions to Fe-removal mechanisms in constructed wetlands. Journal of environmental management, 87, 450, 2008.

31. CHANG Y.-H., KU C.-R., YEH N. Solar powered artificial floating island for landscape ecology and water quality improvement. Ecological engineering, 69, 8, 2014.

32. ZHAO W., ZHENG Z., ZHANG J., ROGER S.-F., LUO $X$. Evaluation of the use of eucalyptus to control algae bloom and improve water quality. Science of the Total Environment, 667, 412, 2019.

33. GAO H., QIAN X., WU H., LI H., PAN H., HAN C. Combined effects of submerged macrophytes and aquatic animals on the restoration of a eutrophic water body - a case study of Gonghu Bay, Lake Taihu. Ecological engineering, 102, 15, 2017.

34. ZHU L., LI Z., KETOLA T. Biomass accumulations and nutrient uptake of plants cultivated on artificial floating beds in China's rural area. Ecological Engineering, 37, 1460, 2011.

35. MA X., MA F., LI C., MI Y., BAI T., SHU H. Biomass accumulation, allocation, and water-use efficiency in 10 Malus rootstocks under two watering regimes. Agroforestry systems, 80, 283, 2010.

36. GE Y., CHANG J., WANG X., XU Q. Relationship between the physiological characters and purification ability of different plants in waters with two trophic levels. Acta Ecologica Sinica, 20, 1050, 2000.

37. ALMUKTAR S., SCHOLZ M., AL-ISAWI R., SANI A. Recycling of domestic wastewater treated by verticalflow wetlands for irrigating chillies and sweet peppers. Agricultural Water Management, 149, 1, 2015. 